\title{
Adverse Effect of Direct Discharge of Hot Spring Tributaries into Rivers on Life Aquatic Ecosystems
}

\author{
$\underline{\text { Yuly Sánchez }}{ }^{1}, M_{\text {ehrab Mehrvar }}^{2}$, Lynda McCarthy $^{3}$, Edgar Quiñones-Bolaños ${ }^{4}$, Luis Cheu ${ }^{5}$, Jairo \\ Chacón' \\ ${ }^{1}$ Escuela Colombiana de Ingeniería “Julio Garavito”, Bogotá, Colombia. yuly.sanchez@escuelaing.edu.co \\ ${ }^{2}$ Department of Chemical Engineering, Ryerson University, 350 Victoria Street, Toronto, ON, Canada M5B 2 K3. \\ mmehrvar@ryerson.ca \\ ${ }^{3}$ Department of Chemistry and Biology, Ryerson University, 350 Victoria Street, Toronto, ON, Canada M5B 2K3. \\ 13mccart@ryerson.ca \\ ${ }^{4}$ Environmental Modelling Group, Faculty of Engineering, University of Cartagena, 130010 Cartagena, Colombia. \\ equinonesb@unicartagena.edu.co \\ 5Escuela Colombiana de Ingeniería "Julio Garavito”, Bogotá, Colombia. luis.rodriguez@escuelaing.edu.co \\ ${ }^{6}$ Escuela Colombiana de Ingeniería “Julio Garavito”, Bogotá, Colombia. jairo.chacon@escuelaing.edu.co
}

\section{Extended Abstract}

Hot springs have traditionally been a tourist attraction in many parts of the world during the high season of tourism. Wastewater is usually discharged into streams without any treatment. This affect the quality of the receiving water, causing negative impacts to the aquatic ecosystems. There has been little research on the downstream ecological impacts of water discharges from various major recreational spa sites in different parts of the world, however, some studies suggest that sewage discharges from hot springs have adverse ecological effects on aquatic life. On the other hand, the mineral composition of hot springs derived mainly from groundwater is greater than that of stream water. There are models that simulate the effects of hot spring discharges into surface water sources. For example, some studies have found that wastewater discharges from hot springs have a significant adverse impact on water quality during periods of minimal flow. However, an important factor that must be taken into account is that it is estimated that the wastewater from the thermal waters contributes up to $50 \%$ of the effluents discharged into the receiving water, which may be the main reason for the significant negative impact of the hot springs over aquatic systems. Despite the negative consequences of the impacts on ecosystems derived from wastewater from hot springs, it is interesting to note that there are no regulations for the discharge of wastewater from hot springs. This may be due to the fact that the amount of effluent that is discharged into the receiving water is generally limited or because the importance of the mineral composition of the hot springs is small compared to that present in the wastewater discharges derived from anthropogenic activities. Therefore, it is necessary to advance in the investigation on the contamination of the waste waters coming from hot springs. The results of these investigations will surely contribute to the authorities increasing control over the use of hot springs and the discharge of their untreated waters [1-9].

Keywords: Aquatic, discharge, ecosystem, effect, hot springs.

\section{References}

[1] Alberta, Environmental Protection and Enhancement Act. (2013). Wastewater and Storm Drainage (Ministerial) Regulation. Canada. Available in: <https://www.canada.ca/en/environment-climatechange/services/wastewater/regulations.html>.

[2] Germany, Federal Ministry of Justice. (1997). Ordinance on requirements for the discharge of wastewater into bodies of water (Wastewater Ordinance - Abwasserverordnung AbwV). 
[3] Lenart, A., Wolanin, A., Jelonkiewicz, L., Chmielewska, Daria \& Żelazny, M, (2016). "Spatiotemporal Variability in Microbiological Water Quality of the Białka River and Its Relation to the Selected Physicochemical Parameters of Water". Water Air Soil Pollut 227: 22.

[4] Taipei Times, Taiwan News. "EPA plans to regulate hot-spring wastewater". October 13 of 2004. Available online: https://www.taipeitimes.com/News/taiwan/archives/2004/10/13/2003206666. (accessed on 12 February 2021).

[5] United States, Environmental Protection Agency (EPA). "Stream Water Quality Model". Available online: https://cfpub.epa.gov/si/si_public_record_Report.cfm?Lab=NERL\&dirEntryID=75862.(accesed on 9 April 2021).

[6] United States, Environmental Protection Agency (EPA). "Authorization to Discharge under the National Pollutant Discharge Elimination System”. Available online: https://www.epa.gov/sites/production/files/201804/documents/mt0020591-hot-springs-final-permit-6mar18.pdf.(accessed on 10 April 2021).

[7] Yan, J., Chan, Y., Wen, C., and Hung, W. (2005). "Impact of hot spring bathing water on the water quality in the NanShih Creek". Journal of the Chinese Institute of Environmental Engineering, Vol. 15, No. 2, pp. 91-99.

[8] Y. Sanchez, M. Mehrvar, L. McCarthy, E. Quiñones, L.R. Cheu, J. Romero, Scientific discussion of selected viruses including COVID-19 in hot springs, Congreso Internacional de Innovación y Tendencias y Ingeniería (VI CONIITI 2020), Bogotá, Colombia, September 30-October 2, 2020, pp. 1-6, doi: 10.1109/CONIITI51147.2020.9240267.

[9] Y. Sanchez, M. Mehrvar, L. McCarthy, E. Quiñones, L.R. Cheu, J. Romero, An overview of the management of COVID-19 in swimming pools, beaches, and hot springs in Europe, Canada, and Colombia, Segundo Encuentro Nacional de Estudiantes de Doctorados en Ingeniería (ENEDI 2020), ACOFI 2020, Centro de Convenciones, Cartagena, Colombia, September 16-18, 2020. pp 296-304. ISBN: 978-958-680-090-7. https://www.acofi.edu.co/eiei2020/wp-content/uploads/2020/10/Memorias-ENEDI-2020.pdf 